ventilation during postnatal development in conscious kitten. J Appl Physiol 56:1464-1471

16. Haddad GG, Gandhi MR, Mellins RB 1982 Maturation of ventilatory response to hypoxia in puppies during sleep. J Appl Physiol 52:309-314

17. Gautier H 1986 Hypoxic enigma: central effects of hypoxia on ventilatory and thermoregulatory control. In: von Euler C, Lagercrantz H (eds) Neurobiology of the Control of Breathing. Raven Press, New York, pp 19-25

18. Karczewski WA 1974 Thermal polypnoea. A non-specific phenomenon. In Proceedings of the 2 nd Symposium on Pharmacology of Thermoregulation, Paris. Karger, Basel, pp 178-182

19. Mortola HP, Gleed R, Saiki C 1991 Adaptation and acclimatization in the hypoxic newborn mammal. In: Frazer DT, Speck DF (ed) Modulation of Respiratory Patterns: Peripheral and Central Mechanisms. University Press of Kentucky (in press)

20. Sidi D, Kuipers JRG, Teitel D, Heymann MA, Rudolph AM 1983 Developmental changes in oxygenation and circulatory responses to hypoxemia in lambs. Am J Physiol 245:H674-H682

21. Sidi D, Kuipers JRG, Heymann MA, Rudolph AM 1983 Effects of ambient temperature on oxygen consumption and the circulation in newborn lambs at rest and during hypoxemia. Pediatr Res 17:254-258

\title{
Announcement
}

\section{Scientific Meeting}

The Society for Behavioral Pediatrics will conduct its 9th Annual Scientific Meeting and Workshops on September 21-23, 1991 at the Omni Inner Habor Hotel in Baltimore, MD. For further information and registration forms, please contact Ms. Noreen Spota at (215) 248-9168. 